Konrad A. Czernielewski

Muzeum Tradycji Niepodległościowych w Łodzi
OBLICZA WOJNY

TOM $2 \cdot A R M I A K O N T R A N A T U R A$

ŁÓDŹ2020 • ISBN 978-83-8220-057-7 • s. 269-290

http://dx.doi.org/10.18778/8220-057-7.13

\title{
SŁUŻBA METEOROLOGICZNA I HYDROGRAFICZNA ARMII II RZECZYPOSPOLITEJ
}

Streszczenie. Autor artykułu omówił dzieje służby meteorologicznej i hydrograficznej Wojska Polskiego w latach 1919-1939. Na początku swych rozważań przedstawił krótki zarys rozwoju obserwacji meteorologicznych i hydrograficznych w Polsce od końca średniowiecza do wybuchu I wojny światowej. Ukazał początki formowania państwowej i wojskowej służby meteorologicznej i hydrograficznej w 1919 r. Szczególnie dużo uwagi poświęcił działalności Państwowego Instytutu Meteorologii - instytucji ściśle współpracującej z Ministerstwem Spraw Wojskowych, Sztabem Generalnym Wojska Polskiego i jego oddziałami.

Przedstawiono także historię służb hydrograficznych Polskiej Marynarki Wojennej. Polska miała przed 1939 r. duże osiągnięcia w badaniach hydrograficznych. Już w 1926 r. została członkiem Międzynarodowego Biura Hydrograficznego z siedzibą w Monako. Oficjalnym reprezentantem Polski w Międzynarodowym Biurze było Biuro Hydrograficzne Marynarki Wojennej.

Autor dużo uwagi poświęcił działalności służb meteorologicznych na rzecz polskiego lotnictwa - głównie wojskowego, ale także współpracy meteorologów wojskowych z polską artylerią oraz służbą uzbrojenia. Omówił problematykę szkolenia służb meteorologicznych i hydrograficznych w Polsce w latach 1918-1939. Przedstawił również strukturę organizacyjną wspomnianych służb oraz ich kadrę dowódczą. Przybliżył czytelnikom kwestie techniczne: przedstawił oprzyrządowanie, sposoby i metody obserwacji zjawisk przyrodniczych, a także ich zapisywanie.

We wnioskach końcowych przedstawił swoją ocenę działalności służb meteorologicznych oraz hydrograficznych Wojska Polskiego. Ocenił je bardzo wysoko - były dobrze zorganizowane i dobrze wyposażone w sprzęt specjalistyczny, współpracowały z licznymi instytucjami naukowymi. Wysoko oceniane były w okresie międzywojennym przez przedstawicieli armii europejskich. Świadczy o tym fakt, iż o informację o organizacji polskich służb meteorologicznych i hydrograficznych poprosił na początku marca 1938 r. attaché wojskowy Finlandii.

Słowa kluczowe: meteorologia, hydrografia, wojskowa służba meteorologiczna, wojskowa służba hydrograficzna, wywiad wojskowy, kontrwywiad wojskowy, marynarka wojenna, lotnictwo wojskowe, artyleria, służba uzbrojenia, Ministerstwo Spraw Wojskowych, Państwowy Instytut Meteorologiczny 
W historii działań bojowych natura odgrywała i odgrywa wielką rolę. Ulewne deszcze, zamiecie śnieżne czy sztormy wpływały na przebieg walk. Te ostatnie można by wymienić jako jedną z przyczyn porażki hiszpańskiej Wielkiej Armady w sierpniu 1588 r., kiedy warunki atmosferyczne sprzyjały głównie stronie angielskiej ${ }^{1}$. Innym wymownym przykładem jest klęska Napoleona Bonapartego w Rosji w 1812 r. ${ }^{2}$, pokonanego nie tylko przez samych Rosjan, ale także przez przyrodę i ogrom terytorium państwa carów. We wrześniu 1939 r. brak opadów, niskie stany rzek były korzystne dla Niemców, a przede wszystkim dla ich broni pancernej i oddziałów zmotoryzowanych. Innymi przykładami z okresu II wojny światowej - wręcz klasycznymi - są: lądowanie w Normandii w czerwcu 1944 r., kiedy czekano na poprawę pogody, lub perypetie operacji „Market-Garden” we wrześniu tegoż roku w Holandii ${ }^{3}$. Zrozumiałe jest zatem, że każdy dowódca chce mieć wiadomości o przewidywanej pogodzie czy stanie rzek na drodze przemarszu własnych wojsk.

W Polsce już w drugiej połowie XV w. prowadzone były tzw. kroniki pogodowe. Notatki te sporządzali profesorowie Wszechnicy Krakowskiej - zwłaszcza zaś ks. Marcin Biem, który sporadycznie prowadził obserwacje meteorologiczne w Krakowie od 1490 r. W latach 1502-1517 zapisywał je już systematycznie. Od 1525 do 1540 r. kontynuował swoje obserwacje w Olkuszu4 . Gwoli ścisłości należy dodać, że w latach wcześniejszych kronikarze odnotowywali niezwykłe zjawiska pogodowe, takie jak chociażby obfite deszcze, wylewy rzek czy długotrwałe susze.

Obszerniejsze informacje z zakresu hydrografii dla ówczesnych i obecnych ziem polskich zawdzięczamy Janowi Długoszowi (1415-1489). Około roku 1470 napisał on pracę Chorografia, wydaną drukiem w latach 1614-1615. Opisał w niej 202 rzeki w dorzeczach Wisły, Odry, Dniepru i Dźwiny oraz 96 jezior $^{5}$. W maju 1655 r. rozpoczęto w Warszawie instrumentalne obserwacje

${ }^{1}$ J. Cummins, Francis Drake, Warszawa 2000, s. 199-213; C. Erickson, Elżbieta I, Warszawa 2001, s. 380-394; K. Dziewanowski, Brzemię biatego cztowieka, t. 1, Warszawa 1981, s. 86-89.

${ }^{2}$ M. Kukiel, Wojna 1812, Poznań 1996, s. 5 i nast.; Wielka historia świata, t. 9: Świat w latach 1800-1850, red. A. Chwalba, Kraków 2006, s. 334-335; S. Grodziski, Polska w czasach przetomu. 1764-1815, Kraków 2001, s. 276-277.

3 Podkreślają to autorzy wielu opracowań - m.in.: S.E. Ambrose, D-Day 6 czerwca 1944, Warszawa 1999; W. MarkerT, Arnhem 1944, Warszawa 2006.

480 lat państwowej stużby hydrologicznej i meteorologicznej w Polsce 1919-1999, Warszawa 1999, s. 12.

5 Ibidem, s. 16. 
meteorologiczne. Wcześniej - od grudnia 1654 r. - prowadzono je tylko w dwóch miastach włoskich: Florencji i Pizie. W Warszawie obserwacje prowadzono w ramach tzw. sieci florentyńskiej. Były one wykonywane jeszcze za pomocą wadliwych urządzeń o różnych i nieporównywalnych skalach. Powstanie i rozwój regularnej sieci stacji obserwacyjnych rozpoczyna się dopiero od drugiej połowy XIX stulecia ${ }^{6}$.

Pierwsze, mniej lub bardziej wiarygodne, obserwacje hydrologiczne, głównie wodowskazowe ${ }^{7}$, zaczęto prowadzić także w połowie XVII w. Natomiast systematyczne obserwacje hydrologiczne rozpoczęto we Wrocławiu w 1717 r., w Gdańsku od roku 1739, a w Toruniu w latach 1760-1772. Wymienić w tym miejscu wypada profesora nauk przyrodniczych Antoniego Magiera prowadzącego od 1799 r. zapisy w księdze założonej przez Zarząd Miejski z codziennych obserwacji stanów wody w Warszawie. A. Magier od 1826 r. notował regularnie swoje obserwacje klimatyczne w Obserwatorium Klimatycznym. Jednakże istotny rozwój stacji hydrologicznych, z szerszym zakresem badania stanu wód, nastąpił dopiero w drugiej połowie XIX stulecia ${ }^{8}$.

W 1764 r. uznając rzeki za naturalne bogactwo narodowe poddano je jurysdykcji Komisji Skarbu Koronnego. Zalecano jednocześnie, aby rzeki uznane za spławne zostały przystosowane do żeglugi. W tym samym roku powstał Korpus Pontonierów, którego powinnością było techniczne przygotowanie rzek w tym celu?

Za panowania króla Stanisława Augusta, wielkiego mecenasa nauki i sztuki, astronom Marcin Poczobutt-Odlanicki w latach $1770-1772$ prowadził w Wilnie regularne pomiary temperatury powietrza. Podobne obserwacje czyniono w Warszawie (ks. Jowin Bystrzycki), we Wrocławiu, w Krakowie, Gdańsku. W 1829 r. ukazała się pierwsza publikacja dotycząca klimatu Warszawy ${ }^{10}$.

${ }^{6} \mathrm{~J}$. ZielińsKi, Polska państwowa stużba hydrologiczno-meteorologiczna w 70-lecie swego istnienia, [w:] 70-lecie państwowej stużby hydrologiczno-meteorologicznej. Referaty problemowe, Warszawa 1989, s. 15.

7 Wodowskaz to urządzenie służące do pomiarów poziomu wody. Umieszcza się je przy rzece lub w rzece w profilu wodowskazowym. J. Flis, Szkolny stownik geograficzny, Warszawa 1985, s. 143.

${ }^{8}$ J. ZiELIŃsKi, op. cit., s. 16-18.

980 lat państwowej stużby hydrologicznej..., s. 18-20.

${ }^{10}$ Ibidem, s. 18. Wspomniana praca miała niezwykle długi tytuł: Karta meteograficzna stolicy Królestwa Polskiego czyli obraz odmian powietrza wystawiajacy graficznym sposobem najważniejsze wypadki z dostrzeżeń meteorologicznych czynionych w Warszawie od 1803 do 1828 roku przez Antoniego Magiera, cztonka Towarzystwa Królewskiego War. Przyjaciót Nauk, utożonych zmianami dtugości dnia 
Polska myśl meteorologiczna i hydrologiczna rozwijała się mimo rozbiorów. Zapewne większość Polaków zna Wincentego Pola jako słynnego poetę, ale był on także hydrografem i oceanografem. W 1849 r. na Uniwersytecie Jagiellońskim powstała Katedra Geografii, którą objął właśnie W. Pol. Do 1912 r. jego podręcznik poświęcony hydrografii był jedynym na ziemiach polskich ${ }^{11}$.

Wkrótce po odzyskaniu niepodległości, bo już na początku 1919 r., utworzono w Polsce państwowe służby hydrologiczne i meteorologiczne. Jeszcze w latach I wojny światowej, na kursie prowadzonym w 1916 r. w Warszawie przez Polskie Towarzystwo Żeglugi Napowietrznej, wykładano przedmiot „Meteorologia Aeronautyczna"12. W styczniu 1919 r. powstało w Warszawie Biuro Hydrograficzne, przemianowane w marcu tegoż roku na Wydział Hydrograficzny w Ministerstwie Robót Publicznych. Na początku lat trzydziestych Wydział zmienił nazwę na Centralne Biuro Hydrograficzne, a z początkiem 1934 r. utworzono Instytut Hydrograficzny podległy Ministrowi Komunikacji ${ }^{13}$.

Inaczej rzecz się miała w przypadku tworzenia służby meteorologicznej. W dniu 28 kwietnia 1919 r. Rada Ministrów wydała rozporządzenie o utworzeniu Państwowego Instytutu Meteorologicznego (PIM) przy Ministerstwie Rolnictwa i Dóbr Państwowych ${ }^{14}$. Instytut otrzymał statut 23 maja 1922 r., w którym nazwano go: „wyższym zakładem naukowo-badawczym, jednoczącym całokształt państwowej służby meteorologicznej na obszarze Rzeczypospolitej Polskiej, nie wyłączając służby dla potrzeb wojskowych"15. Zadaniem państwowej służby meteorologicznej było: organizowanie i prowadzenie badań naukowych; organizowanie służby pogody oraz wszelkich innych służb meteorologicznych, ze szczególnym uwzględnieniem potrzeb rolnictwa, wojskowości, lotnictwa, marynarki, komunikacji lądowej i wodnej oraz wykorzystania rzek na potrzeby komunikacji oraz energetyki (elektrownie wodne).

W 1932 r. powstała koncepcja połączenia państwowych instytutów - Hydrograficznego i Meteorologicznego w jeden organizm prowadzący służbę

obliczonymi na szerokoś́ jeogr. Warsz. pomnożony przez Wojciecha Jastrzębowskiego z dotączeniem osobnego objaśnienia potrzebnego dla użycia tej karty.

${ }_{11}$ Ibidem, s. 20. W 1912 r. ukazała się praca Ludomira SAWiCKiego, Hydrografia ziem polskich.

12 P. Rapiński, Lotnictwo Armii „Łódż”, Łódź 2018, s. 17. Wykładowcą był dr Władysław Gorczyński.

1380 lat państwowej stużby hydrologicznej..., s. 22-25.

14 „Dziennik Praw Państwa Polskiego” 1919, nr 39, poz. 290, s. 482-483.

15 „Dziennik Ustaw” 1922, nr 44, poz. 373, s. 683-685. 
hydrologiczno-meteorologiczną. Podjęto nawet uchwałę Rady Ministrów, ale nie została ona zrealizowana przed wybuchem II wojny światowej ${ }^{16}$.

Początki służby meteorologicznej odrodzonego Wojska Polskiego (WP) sięgają początków 1919 r. Już w połowie stycznia Sekcja Żeglugi Napowietrznej Ministerstwa Spraw Wojskowych (MSWojsk.) nawiązała współpracę techniczną w kwestii naprawy wojskowego sprzętu meteorologicznego przez stację w Mokotowie. Natomiast poważniejsze naprawy zlecano fabryce „Gerlach”, firmie powstałej w $1760 \mathrm{r}$. w Warszawie ${ }^{17}$.

W 1919 r. rozpoczęto nabór i szkolenie kadr do służby meteorologicznej. Kierowano tam głównie pilotów oraz personel naziemny sił powietrznych ${ }^{18}$. W tym okresie częste były prośby Wojskowej Stacji Meteorologicznej do Inspektoratu Wojsk Lotniczych o przysłanie doświadczonych meteorologów cywilnych ${ }^{19}$. Prowadzono także szkolenia z zakresu wiedzy meteorologicznej dla artylerzystów. Szef szwadronu, francuski oficer Toussaint (imienia nie ustalono), kierujący kursem artylerii Armii Polskiej sformowanej we Francji, podkreślał w sierpniu 1919 r. konieczność uwzględniania informacji meteorologicznych podczas prowadzenia ognia artyleryjskiego. Artylerzyści zmuszeni są bowiem do uwzględniania takich czynników, jak siła wiatru, wilgotność powietrza, zamglenia itp. ${ }^{20}$, które w dużym stopniu wpływają na celność i skuteczność ostrzału.

Na początku 1920 r. oficerowie Departamentu Artylerii MSWojsk., w okresie toczącej się wojny z Rosją, doceniając potrzebę zakupu stacji meteorologicznych we Francji zastanawiali się, czy odrodzone państwo polskie będzie stać na zakup kosztownych urządzeń. Podkreślali fakt, iż duże środki finansowe pochłonie także szkolenie personelu. Stwierdzili w piśmie do Naczelnego Dowództwa WP (NDWP) z końca stycznia 1920 r., że: „uprasza się o zawiadomienie, czy

1680 lat państwowej stużby bydrologicznej..., s. 28.

17 Centralne Archiwum Wojskowe w Wojskowym Biurze Historycznym [dalej: CAW WBH], Ministerstwo Spraw Wojskowych [dalej: MSWojsk.] Dowództwo Lotnictwa, sygn. I.300.38.112. Pismo Departamentu Technicznego Sekcji Żeglugi Napowietrznej MSWojsk. do Dowództwa Wojsk Lotniczych z 17 I 1919 r.; Pismo Wojskowej Głównej Stacji Meteorologicznej z 17 VI 1919 r.

18 CAW WBH, MSWojsk. Inspektorat Wojsk Lotniczych, sygn. I.300.39.16. Pismo Głównej Wojskowej Stacji Meteorologicznej z 19 III 1919 r.

19 CAW WBH, Naczelne Dowództwo Wojska Polskiego [dalej: NDWP], Szefostwo Lotnictwa, sygn. I.301.12.3. Pismo Wojskowej Stacji Meteorologicznej w Warszawie z 1 VIII 1919 r.

${ }^{20}$ CAW WBH, MSWojsk. Inspektorat Wojsk Lotniczych, sygn. I.300.39.16. Raport szefa szwadronu Toussaint z 11 VIII $1919 \mathrm{r}$. 
warunki walk na naszych frontach będą wymagały i dadzą możność instalacji wspomnianych stacji oraz - w razie odpowiedzi twierdzącej - w jakiej ilości należy wspomniane stacje we Francji zakupić”. Odpowiadając Naczelne Dowództwo stwierdziło, że dowództwa frontów składają już zapotrzebowania na stacje meteorologiczne ${ }^{21}$. Dodajmy, że już na początku stycznia 1920 r. Generalny Inspektorat Artylerii MSWojsk. zwrócił się do I Wiceministra Spraw Wojskowych gen. ppor. Stefana Majewskiego z prośbą o zakup oprócz amunicji i tarcz strzelniczych, także jednej stacji meteorologicznej we Francji ${ }^{22}$.

W dniu 19 lutego 1920 r. utworzono Urząd Hydrograficzny Polskiej Marynarki Wojennej, którego szefem został kpt. mar. Józef Unrug ${ }^{23}$, od 1925 r. dowódca Floty w Gdyni ${ }^{24}$. W roku 1919 na potrzeby floty zakupiono w Hamburgu statek „Wotan”, który w Marynarce Wojennej otrzymał nazwę ORP „Pomorzanin”. Okręt ten wykorzystywano do prowadzenia obserwacji hydrologicznych i meteorologicznych ${ }^{25}$. Natomiast pierwsza polska stacja meteorologiczna działała w Wolnym Mieście Gdańsku. Jednakże już pod koniec 1921 r. rozważano konieczność jej przeniesienia na terytorium II Rzeczypospolitej ${ }^{26}$. Stało się to realne po zbudowaniu portu handlowo-pasażerskiego w Gdyni w 1923 r., a w trzy lata później portu wojennego na Oksywiu w Gdyni ${ }^{27}$.

Od początku lat dwudziestych w polskich siłach powietrznych prowadzono regularne obserwacje meteorologiczne. Na przykład w marcu 1922 r. „spostrzeżenia meteorologiczne" prowadziły stacje w: Warszawie, Rembertowie, Poznaniu (lotnisko w Ławicy), Toruniu, Bydgoszczy, we Lwowie i w Krakowie ${ }^{28}$.

${ }^{21}$ CAW WBH, Oddział IV NDWP, sygn. I.301.10.164. Pismo Departamentu Artylerii MSWojsk. do NDWP z 26 I 1920 r.; Odpowiedź NDWP z 15 (?) I 1920 r. Data na dokumencie ubrudzona tuszem.

22 Ibidem, Pismo Generalnego Inspektoratu Artylerii do I Wiceministra MSWojsk. z 4 I 1920 r.

23 Z. Kopacz, W. Morgaś, W. Kierzkowski, H. Nitner, Powstanie Urzędu Hydrograficznego Marynarki Wojennej, „Nautologia” 1999, t. 34, nr 2, s. 30; https://docplayer.pl/37259188-kalendarium-sluzby-hydrograficznej [dostęp: 21 X 2019].

${ }^{24}$ M. Borowiak, Admirat. Biografia Józefa Unruga, Gdańsk 2004, s. 73 i nast.

25 J. Micıński, Księga statków polskich 1918-1945, t. 1, Gdańsk 1996, s. 122-130; J. PiwowońSKI, Flota spod biato-czerwonej, Warszawa 1989, s. 239-240.

${ }^{26}$ CAW WBH, Oddz. IV Sztabu Generalnego [dalej: SG], sygn. I.303.7.32. Protokół konferencji międzyministerialnej w sprawie radiostacji i stacji meteorologicznej w Gdańsku z 14 XII $1921 \mathrm{r}$.

27 C. Ciesielski, W. Pater, J. Przybylski, Polska Marynarka Wojenna 1918-1980. Zarys dziejów, Warszawa 1992, s. 22-32.

${ }^{28}$ CAW WBH, MSWojsk. Dowództwo Lotnictwa, sygn. I.300.38.112. Zestawienie spostrzeżeń meteorologicznych za miesiąc marzec $1922 \mathrm{r}$. 
W lutym 1922 r. doszło do porozumienia między Służbą Hydrograficzną (d. Urzędem) Marynarki Wojennej i Państwowym Instytutem Meteorologicznym. W rezultacie tego porozumienia powołano do życia Wydział Morski PIM. Jesienią 1926 r. zorganizowano w Wydziale Morskim służbę sygnalizacyjną zagrożenia lodami. Stacje lodowe działały w Rozewiu, na Helu, w Gdyni i w Tczewie. Po rozbudowie portu w Gdyni przeniesiono Wydział z Gdańska do Gdyni. Z uwagi na to, że zadania hydrografii przekazano władzom cywilnym - PIM, 25 lutego 1922 r. wycofano ze służby ORP „Pomorzanin”29.

W wyniku kolejnego porozumienia Marynarki Wojennej i PIM, ale także dowództwa Floty, Polskiej Akademii Umiejętności oraz instytucji naukowo-badawczych - przekształcono Wydział Morski w Obserwatorium Morskie. Na początku lat trzydziestych ponownie zmieniono nazwę placówki, powołując do życia Oddział Morski PIM, z siedzibą w Gdyni przy ul. Jerzego Waszyngtona 42. Od 1 czerwca 1931 r. aż do wybuchu wojny kierował pracami Obserwatorium Morskiego, a potem Oddziału - adiunkt kpt. żeglugi wielkiej Stanisław Dłuski, dawny oficer rosyjskiej marynarki wojennej i dyrektor Szkoły Morskiej w Baku. S. Dłuski jednocześnie wykładał w Państwowej Szkole Morskiej w Gdyni ${ }^{30}$.

W dniu 2 czerwca 1922 r. Służba Hydrograficzna Marynarki Wojennej otrzymała nazwę Biura Hydrograficznego, a od grudnia tegoż roku jego szefem był kpt. mar. Jerzy Kłossowski, absolwent francuskiej École Hydrographique. Funkcję tę pełnił do 1925 r., będąc jednocześnie dowódcą ORP „Pomorzanin”, która to jednostka powróciła do służby w polskiej flocie wojennej. Postarał się o to sam kpt. mar. J. Kłossowski uznając, iż: „Hydrografia morska bez okrętu hydrograficznego równa się kawalerji bez konia i jest przeto zjawiskiem anormalnym"31. Pomysłowi temu przeciwny był ówczesny dowódca Floty kmdr Jerzy Świrski, ale na szczęście innego zdania był szef Kierownictwa Marynarki

${ }^{29}$ CAW WBH, Departament Spraw Morskich i Kierownictwo Marynarki Wojennej, sygn. I.300.21.82. Skreślenie ORP „Pomorzanin” z listy okrętów wojennych; K. RóżDżyński, E. STAChurska, Polska stużba meteorologiczna i hydrologiczna na Morzu Battyckim w latach 1920-1988, [w:] 70-lecie Państwowej..., s. 122-123.

${ }^{30}$ K. Różdżyński, E. Stachurska, op. cit., s. 123-124; R. Osowicka, Piaśnica. Miejsce martyrologii i pamięci, Wejherowo 2001. S. Dłuski (1881-1939), został zamordowany przez Niemców w lasach piaśnickich (na północny-zachód od Wejherowa).

${ }^{31}$ CAW WBH, Departament Spraw Morskich i Kierownictwo Marynarki Wojennej, sygn. I.300.21.412, Memoriał w sprawie Służby Hydrograficznej Morskiej, s. 5-33; D. NAwrot, Historia korpusu oficerskiego Marynarki Wojennej II Rzeczypospolitej. Post scriptum, „Zeszyty Naukowe Akademii Marynarki Wojennej" 2011, t. 52, nr 1, s. 177-178; Kadry morskie Rzeczypospolitej Polskiej, t. 5: Polska 
Wojennej kontradm. Kazimierz Porębski. Jerzy Kłossowski uważał, że: „Komandor Świrski bardzo czuły pod względem swego prestiżu, nie mógł się pogodzić z myślą, że wśród podległych mu jednostek znajdzie się okręt, wprawdzie mały, ale nad którym nie będzie sprawować władzy"32. W rezultacie ORP „Pomorzanin” znów znalazł się w składzie okrętów Marynarki Wojennej ${ }^{33}$, aż do 14 lutego 1932 r., kiedy to został wycofany ze służby. Zastąpił go trałowiec „Mewa”, który został przebudowany na okręt hydrograficzny i przemianowany na ORP „Pomorzanin” ${ }^{4}$.

W lipcu 1926 r. Polska została członkiem Międzynarodowego Biura Hydrograficznego z siedzibą w Monako. Wstąpienie do tej organizacji przyniosło nie tylko wymierne korzyści związane z dostępem do nowych technik pomiarowych czy danych i informacji z zakresu hydrografii. Miało także pewien aspekt polityczny i propagandowy - było to uznanie faktu istnienia Rzeczypospolitej Polskiej nad Bałtykiem. Oficjalnym reprezentantem Polski w Międzynarodowym Biurze w Monako było Biuro Hydrograficzne Marynarki Wojennej35.

Biuro Hydrograficzne Marynarki Wojennej zakończyło swą działalność 4 września 1939 r., gdy ówczesny jego szef - kmdr ppor. Artur Reyman otrzymał rozkaz o jego likwidacji: „w sensie zniszczenia wszystkich dokumentów i akt tajnych"36.

Drugim rodzajem sił zbrojnych, który obok floty wojennej w szerokim zakresie wykorzystywał obserwacje meteorologiczne, było polskie lotnictwo. Z problematyką meteorologii młodzi adepci latania zapoznawali się już na etapie nauki

Marynarka Wojenna. Dokumentacja organizacyjna i kadrowa oficerów, podoficerów i marynarzy 1918-1947, red. J.K. SAWICKI, Gdynia 2011, s. 205.

32 J. KŁossowski, Wspomnienia z Marynarki Wojennej, Warszawa 1977, s. 205.

33 CAW WBH, Oddziały Marynarki Wojennej, sygn. I.328.1.4. Rozkaz Dowództwa Floty nr 17 z 22 lutego $1924 \mathrm{r}$.

${ }^{34}$ CAW WBH, Departament Spraw Morskich i Kierownictwo Marynarki Wojennej, sygn. I.300.21.82. Skreślenie ORP „Pomorzanina” z listy okrętów wojennych. Nowy „Pomorzanin” był trałowcem redowym niemieckiego typu FM. Został zatopiony 14 IX 1939 r. przez lotnictwo niemieckie w porcie w Jastarni.

${ }^{35}$ H. Nitner, Początki wspótpracy międzynarodowej $w$ dziedzinie hydrografii morskiej, „Przegląd Morski” 1995, R. 48, nr 9, s. 30; A. ŁysEjko, 70-lecie hydrografii w Polsce, „Przegląd Morski” 1990, R. 43, s. 13; https://docplayer.pl/37259188-kalendarium-sluzby-hydrograficznej [dostęp: 21 X 2019]; htps://pl.wikipedia.org/wiki/Biuro-Hydrograficzne_Marynarki_Wojennej [dostęp: 12 X 2019].

${ }^{36}$ H. Nitner, op. cit., s. 30. A. Reyman był szefem Biura Hydrograficznego w latach 1933-1939. 
w Szkole Podchorążych Lotnictwa ${ }^{37}$. W sierpniu 1925 r. w ramach mobilizacji służby meteorologicznej przewidywano m.in., że w Warszawie będzie zmobilizowanych siedem plutonów tej służby ${ }^{38}$. Już w 1926 r. opracowano instrukcję organizacyjną lotnictwa, w której w dużej części uwagę poświęcono organizacji i pracy służby meteorologicznej39. Znalazła się tam informacja, iż: „Wojskowa Stacja Meteorologiczna [w Warszawie - K.A.Cz.] składa się z: a) drużyny komendanta stacji, b) personelu obsługi stacji. Komendant Wojskowej Stacji Meteorologicznej wojskowo [podlega - K.A.Cz.] Komendantowi Głównego Portu Lotn., a pod względem fachowym podporządkowany jest ministrowi (szefowi Departamentu) i odpowiedzialny jest za sprawne funkcjonowanie służby meteorologicznej i spełnianie wszystkich zadań”. Natomiast wojskowe posterunki meteorologiczne były organami wykonawczymi służby meteorologicznej do dyspozycji komendantów lotnisk, ewentualnie komendantów garnizonów. W instrukcji stwierdzono, że posterunki stacjonujące na poligonach artyleryjskich podporządkowane są dowódcom dywizjonów bądź pułków artylerii. Natomiast „Komendant posterunku meteorologicznego wraz z całym personelem podlega komendantowi portu lotniczego [lotniska], zaś w sprawach fachowych otrzymuje wskazówki wprost od komendanta Wojsk. Stacji Meteorologicznej”ł0

W roku 1927 Wydział Aerologiczno-Wojskowy PIM przygotował raport w którym napisano, że „P.I.M. stale dąży do zorganizowania i rozwoju systematycznych obserwacji aerologicznych przy posterunku aerologicznym Kompanji Balonów Zaporowych w Jabłonnie. W tem celu Wydział projektuje urządzenie specjalnej stacji latawcowej [...] Jednocześnie P.I.M. zaznacza, że dla pomiarów aerologicznych nader doniosłe znaczenie posiadają balony zaporowe, za pomocą których na wiosnę roku zeszłego były osiągnięte bardzo dobre rezultaty”¹ ${ }^{\text {. }}$

${ }^{37}$ CAW WBH, Szkoła Podchorążych Lotnictwa (grupa techniczna), sygn. I.340.52.7 oraz I.340.52.8. Wykazy uposażenia za lata 1937-1938. Na etatach Szkoły byli zatrudnieni także meteorolodzy cywilni.

${ }^{38}$ CAW WBH, Oddz. I SG, sygn. I.303.3.204. Tabele mobilizacyjne. 7-c - Stużba meteorologiczna, s. 2-3.

${ }^{39}$ CAW WBH, Oddz. I SG, sygn. I.303.3.97. Tymczasowa instrukcja organizacji lotnictwa na stopie pokojowej, k. 11.

${ }^{40}$ Ibidem, k. 12-14.

${ }^{41}$ CAW WBH, MSWojsk. Dowództwo Lotnictwa, sygn. I.300.38.112, Raport Państwowego Instytutu Meteorologicznego [dalej: PIM] do Departamentu Lotniczego MSWojsk. z 17 I 1927 r. 
W tym samym 1927 r. regularne komunikaty meteorologiczne zaczęła nadawać radiostacja flotylli rzecznej Marynarki Wojennej w Pińsku. Kierownictwo Wojska Polskiego zalecało, aby „Radjostacja Marynarki Wojennej w Pińsku nadawała komunikaty meteorologiczne stale na jednej i tej samej długości fali, oraz posługiwała się jednym i tym samym sygnałem wywoławczym”. Polecono również przekazywanie tychże komunikatów do stacji Brześć nad Bugiem na potrzeby lotnictwa wojskowego ${ }^{42}$.

W 1927 r. nawiązano współpracę z Polskim Radiem, aby nadawać komunikaty meteorologiczne za jego pośrednictwem ${ }^{43}$. Istotną kwestią w pracy służby meteorologicznej, podobnie jak i hydrograficznej, jest bowiem problem szybkiego przekazu informacji. W czerwcu 1927 r. Departament IV Żeglugi Powietrznej MSWojsk. podjął decyzję o wyposażeniu eskadr lotniczych w radiostacje, aczkolwiek m.in. 6 Pułk Lotniczy we Lwowie uskarżał się na ich brak. Podobne obiekcje zgłaszało także dowództwo 2 Pułku Lotniczego w Krakowie. W czasie ćwiczeń w 1927 r. eskadry lotnicze zostały wyposażone w patrole meteorologiczne. Komunikaty meteorologiczne były nadawane przez Centralną Radiostację Warszawa-Cytadela na fali $1111 \mathrm{~m}$ w godzinach 6.00, 12.00 i 22.00, a na fali 2050 m w godzinach: 5.30, 9.30, 13.30 i $15.30^{44}$. Meteorologiczne służby obserwacyjno-meldunkowe w zakresie obrony przeciwlotniczej współpracowały także z Ministerstwem Poczt i Telegrafów, Ministerstwem Komunikacji, Ligą Obrony Powietrznej i Przeciwgazowej oraz Przysposobieniem Wojskowym - zwłaszcza Lotniczym ${ }^{45}$.

Jedną z bolączek służb meteorologicznych był brak żołnierzy potrafiących obsługiwać wyspecjalizowany sprzęt. W czerwcu 1927 r. płk art. Eugeniusz Gałuszczyński szef IX Okręgowego Szefostwa Artylerii w piśmie do szefa Departamentu Lotnictwa MSWojsk. płk. Ludomiła Rayskiego prosił o delegowanie

42 CAW WBH, MSWojsk. Dowództwo Lotnictwa, sygn. I.300.38.112, Telegramy do MSWojsk. z 5 i 30 III, 2 i 29 IV, 27 i 30 V 1927 r.

${ }^{43}$ CAW WBH, MSWojsk. Dowództwo Lotnictwa, sygn. I.300.38.112, Pismo PIM do kpt. K. Zacharewicza Komendanta Wojskowej Głównej Stacji Meteorologicznej Mokotów - Lotnisko z 30 III $1927 \mathrm{r}$.

${ }^{44}$ CAW WBH, MSWojsk. Dowództwo Lotnictwa, sygn. I.300.38.112. Telegram Departamentu IV Żeglugi Powietrznej MSWojsk. z 23 V, 1 i 22 VI 1927 r.

45 A. Stachula, Obrona powietrzna Polski 1918-1939, cz. 1, Jelenia Góra 2009, s. 121-122. W okresie międzywojennym funkcjonowało wiele rodzajów Przysposobienia Wojskowego: Kobiet, Konne (tzw. krakusi), Łączności, Kolejowe itp. 
dwóch, a nawet jednego przeszkolonego szeregowego do obsługiwania stacji meteorologicznej w Obozie Ćwiczebnym Leśna na okres od 30 czerwca do 11 lipca 1927 r. $^{46}$

Przy organizacji pracy służb meteorologicznych instytucje takie, jak PIM czy Departament IV MSWojsk. współpracowały z Ligą Obrony Powietrznej i Przeciwgazowej ${ }^{47}$. W Radzie PIM zasiadali pod koniec lat dwudziestych przedstawiciele m.in.: Ministerstwa Komunikacji, Towarzystwa Naukowego Warszawskiego, Uniwersytetu Warszawskiego, Kierownictwa Marynarki Wojennej, Politechniki Warszawskiej, Departamentu Żeglugi Powietrznej MSWojsk., Ministerstwa Rolnictwa, Ministerstwa Poczt i Telegrafów, Politechniki Lwowskiej, Polskiej Akademii Umiejętności, Uniwersytetu Jagiellońskiego i Uniwersytetu Wileńskiego. Rada PIM: 1) opiniowała sprawozdania z działalności Instytutu, 2) rozpatrywała preliminarze budżetu PIM, 3) brała udział w opracowywaniu regulaminów Instytutu i projektów wszelkich ustaw dotyczących Instytutu, 4) wydawała opinię w sprawach mianowania dyrektora, wicedyrektora oraz kierowników wydziałów Instytutu, 5) wydawała opinię w sprawie mianowania korespondentów PIM oraz 6) wydawała fachowe opinie w sprawach przekazywanych Radzie przez Ministerstwo Rolnictwa lub dyrektora Instytutu ${ }^{48}$. Dobrze układała się także współpraca z Polską Linią Lotniczą „Aerolot” S.A. ${ }^{49}$

W latach dwudziestych sprzęt meteorologiczny kupowano głównie we Francji, w następnej dekadzie także w Wielkiej Brytanii. W 1936 r. m.in. zinicjatywy gen. Leona Berbeckiego rozpoczęto budowę Obserwatorium Astronomiczno-Meteorologicznego im. Marszałka Józefa Piłsudskiego na szczycie Pop Iwan w południowo-wschodnim krańcu pasma Czarnohory w Beskidach Wschodnich $^{50}$. Na potrzeby otwartego 29 lipca 1938 r. obserwatorium zakupiono wiele nowoczesnych urządzeń do prowadzenia obserwacji astronomicznych oraz meteorologicznych. Z tych ostatnich korzystało głównie polskie lotnictwo.

46 Ibidem.

47 CAW WBH, MSWojsk. Dowództwo Lotnictwa, sygn. I.300.38.112. Pismo PIM nr 4252 z 7 IX 1927 r.

48 CAW WBH, MSWojsk. Departament Budownictwa, sygn. I.300.63.5. Protokół XIV posiedzenia Rady PIM z dnia 13 VI 1927 r.

49 CAW WBH, MSWojsk. Dowództwo Lotnictwa, sygn. I.300.38.112. Pismo Polskich Linii Lotniczych „Aerolot” S.A. do Departamentu Żeglugi Powietrznej MSWojsk. z 13 VII 1927 r.

50 Obecnie w obwodzie iwanofrankiwskim (Ukraina). 
Dodajmy, że było to jedno z dwóch najnowocześniejszych obserwatoriów w Europie pod koniec lat trzydziestych ${ }^{51}$.

W latach trzydziestych głównie w polskich firmach kupowano oprzyrządowanie i surowce potrzebne do pracy służby meteorologicznej WP. Na przykład w 1931 r. w „Firmie Przemysłowo-Handlowej Zakłady Chemiczne Ludwik Spiess i Syn" zakupiono kwas siarkowy, menzurki do kwasu oraz areometry ${ }^{52}$.

W czerwcu 1936 r. opracowano organizację służby lotnictwa na stopie wojennej, w tym Wojskowej Służby Meteorologicznej, którą zatwierdził ówczesny szef Sztabu Głównego gen. bryg. Wacław Stachiewicz. Przewidywano, że w skład kierownictwa Wojskowej Służby Meteorologicznej będzie wchodził kierownik (na etacie ppłk. - mjr.) mający do dyspozycji trzyosobową kancelarię, sekcję synoptyczną (17 etatów - w tym trzech synoptyków w stopniach ppor. - por.), sekcję spostrzeżeń (16 etatów), składnicę sprzętu meteorologicznego (pięć etatów), kompanię szkolną (w tym kucharzy, krawca, szewca i kierowcę) $)^{53}$.

W 1937 r. opracowano program mobilizacji służby meteorologicznej polskich sił powietrznych na okres wojny. Każdy pułk lotniczy wystawiał stacje, patrole i posterunki meteorologiczne. Czas sformowania od momentu ogłoszenia mobilizacji to z reguły od 18 do 24 godzin. Krótszy czas przewidywano jedynie dla posterunków meteorologicznych nr: I/1 oraz III/1 wystawianych przez 1 Pułk Lotniczy w Warszawie, bo tylko 12 godzin. W 1937 r. przygotowywano się raczej do wojny z ZSRR niż z Niemcami, stąd najwięcej jednostek meteorologicznych miał wystawić 5 Pułk Lotniczy w Lidzie: 1 stację, 3 posterunki oraz 11 patroli. Z kolei 6 Pułk we Lwowie miał sformować 2 stacje, 2 posterunki i 9 patroli. Inne pułki lotnicze w planach mobilizacyjnych wystawiały przeciętnie po 1 stacji, 2 posterunki i 4 patrole ${ }^{54}$.

$\mathrm{Na}$ potrzeby polskich sił powietrznych w Warszawie w latach trzydziestych prowadzono także kursy meteorologiczne dla wojskowych służb osłony

${ }^{5}$ W. Midowicz, O Biatym Stoniu na Czarnohorze, „Harnaś. Materiały szkoleniowe Studenckiego Koła Przewodników Górskich Harnasie”, Gliwice 1979, s. 3-13; https://pl.wikipedia.org/wiki/ Obserwatorium_Astronomiczno_Meteorologiczne_na_szczycie_Pop_Iwan [dostęp: 31 X 2019].

52 CAW WBH, Biuro Kontroli, sygn. I.300.17.105. Zamówienie nr 269/30-31 Wojskowego Zakładu Zaopatrzenia Inżynierii. Areometry służyły do mierzenia gęstości cieczy.

${ }^{53}$ CAW WBH, Oddz. I SG, sygn. I.303.3.97. Organizacja służby lotnictwa na stopie wojennej. Kierownictwo Wojskowej Stużby Meteorologicznej, k. 29-97.

${ }^{54}$ CAW WBH, Oddz. I SG, sygn. I.303.3.230. Plan mobilizacji służby meteorologicznej z 1937 r., k. 33-139; J. Pawlak, Polskie eskadry w latach 1918-1939, Warszawa 1989, s. 47-145, 316-372. 
lotnictwa ${ }^{55}$. Na początku roku 1937 w celu koordynacji prac nad obroną przeciwlotniczą, z istotnym wykorzystaniem służby meteorologicznej, utworzono Dowództwo Obrony Przeciwlotniczej MSWojsk. ${ }^{56}$

Wróćmy teraz do spraw wojsk lądowych. Już w 1920 r. rozumiano znaczenie meteorologii dla prowadzenia ognia artyleryjskiego. W piśmie Szefostwa Lotnictwa z 20 lutego tegoż roku znalazło się stwierdzenie: „Dla wstrzeliwania artylerii za pomocą obserwacji z samolotów ma służba meteorologiczna wielką wartość, ponieważ pozwala z powodu dokładniejszego strzelania znacznie skrócić czas wstrzeliwania i czas lotu. W przyszłości dla odbioru komunikatów meteorologicznych brygada artyleryjska będzie mogła korzystać z zapasowej dywizyjnej radiostacji nadawczo-odbiorczej"57. W Centralnym Archiwum Wojskowym w Warszawie zachowały się raporty z lotów rozpoznania meteorologicznego pola walki, połączonej niekiedy z rozrzucaniem ulotek do nieprzyjacielskich żołnierzy. W raporcie z marca 1920 r. stwierdzono „warunki atmosferyczne: silny wiatr wschodni u góry, na dole spokojny, niebo czyste [...] obstrzał z ziemi: nie widziano"58.

W 1929 r. wystąpiły kłopoty z organizacją służby meteorologicznej dla artylerii dywizyjnej jednostek piechoty. W związku z tym Sztab Główny WP postulował w sierpniu 1929 r., aby powierzyć formowanie posterunków obserwacyjnych Głównej Wojskowej Stacji Meteorologicznej, ich zaś mobilizację pułkom lotniczym ${ }^{59}$.

Do badań meteorologicznych często wykorzystywano wojskowe balony zaporowe. W drugiej połowie lat dwudziestych zwracano uwagę na to, że: „Opieka meteorologiczna nie może ograniczać się jedynie co do sygnalizowania stanu drogi powietrznej i wydawania zastrzeżeń w postaci 6-godzinnych prognoz pogody, wymaga bowiem również szeregu prac badawczych, których celem jest naukowe badanie pewnych czynników meteorologicznych co do ich zakłócającego, względnie sprzyjającego wpływu na komunikację powietrzną, pozatem opracowywanie metod badania tych czynników i przewidywanie ich

\footnotetext{
5580 lat państwowej stużby hydrologicznej..., s. 26.

56 A. Stachula, op.cit., s. 241.

57 CAW WBH, Oddz. IV NDWP, sygn. I.301.10.164. Pismo szefostwa lotnictwa z 20 II 1920 r.

58 CAW WBH, NDWP Szefostwo Lotnictwa, sygn. I.301.18.19. Lot bojowy dn. 25 marca 1920 r. Eskadry Lotniczej nr 1.

59 CAW WBH, Oddział I SG, sygn. I.303.3.277. Mobilizacja służby meteorologicznej. Projekt reorganizacji z 12 VIII 1929, k. 139-140.
} 
przebiegu"60. W tej dziedzinie Wydział Aerologiczno-Wojskowy PIM współpracował z Główną Wojskową Stacją Meteorologiczną i częściowo z Wydziałem Lotniczym Ministerstwa Komunikacji. W 1930 r. Polska mogła pochwalić się już na arenie europejskiej sprawnie działającą służbą meteorologiczną oraz hydrograficzną $\mathrm{WP}^{61}$.

W połowie lat trzydziestych na wyposażeniu wojskowych stacji meteorologicznych znajdowały się: barometr rtęciowy z termometrem, termometr różnicowy podający najniższą i najwyższą temperaturę w wybranym okresie i czasie, hygrometr samopiszący mierzący wilgotność powietrza, psychometr ze skalą papierową do mierzenia wilgotności powietrza oraz wiatromierz ${ }^{62}$.

Na początku lat trzydziestych wyniki badań meteorologicznych podawano $\mathrm{w}$ formie meteogramów, czyli informacji o temperaturze, temperaturze odczuwalnej i opadach na danym obszarze kraju ${ }^{63}$. Dodajmy, że w latach 1919-1939 PIM we współpracy z Centralnym Biurem Hydrograficznym Ministerstwa Robót Publicznych wydawał również miesięcznik „Wiadomości Meteorologiczne i Hydrograficzne. Bulletin Météorologique et Hydrographique"64. Wojskowa służba meteorologiczna współpracowała także z Wyższą Szkołą Wojenną. W piśmie do jej komendanta gen. dyw. Tadeusza Kutrzeby, kierownik Wojskowej Służby Meteorologicznej płk pil. Kazimierz Zacharewicz raportował: „przedstawiam w załączeniu ilości dni z częściowym i całkowitym zachmurzeniem, chmurami o różnych podstawach, zestawienie ilości dni nienadających się do lotu na zadania rozpoznania, oraz zestawienia ilości dni z mgłą i opadami [...] O ile dokładne opracowania byłyby dla Wyższej Szkoły Wojennej konieczne, to Kierownictwo Wojskowej Służby Meteorologicznej może przystąpić do opracowań statystycznych co najmniej za okres pięcioletni, będzie to jednak wymagać dłuższego czasu"65.

${ }^{60}$ CAW WBH, MSWojsk. Dowództwo Lotnictwa, sygn. I.300.38.112, Pismo PIM nr 4457 z 19 IX 1927 r.

${ }^{61}$ CAW WBH, Oddz. I SG, sygn. I.303.3.26. Rapport sur l'organisation et le fonctionnement du service hydrographique de l'État en Pologne, Cracovie 1930.

${ }^{62}$ CAW WBH, Wojskowe Zakłady Przetwarzania, sygn. I.362.1.153. Tymczasowa instrukcja obsługi stacji meteorologicznej z 23 IX $1933 \mathrm{r}$.

${ }^{63}$ CAW WBH, Dowództwo Lotnictwa MSWojsk., sygn. I.300.38.112. Raporty Departamentu Aeronautyki MSWojsk. z 2 II i 7 III 1930 r.

${ }^{64}$ CAW WBH, Sztab Lotniczy SG, sygn. I.303.10.27. Był to miesięcznik. Ponadto wydawano suplement - np. Przeglad pogody w miesiacu wrześniu 1935.

${ }^{65}$ CAW WBH, Wyższa Szkoła Wojenna, sygn. I.340.1/152. Pismo Kierownictwa Wojskowej Służby Meteorologicznej z dn. 14 IV 1939 r.; Rocznik Oficerski 1939. Stan na dzień 23 marca 1939, 
Pod koniec lat trzydziestych wojskowa służba meteorologiczna stanowiła część składową państwowej służby meteorologicznej, zachowując odrębny charakter pod względem organizacyjnym oraz dyspozycyjnym. Zakres zadań Kierownictwa Wojskowej Służby Meteorologicznej obejmował trzy działy pracy. Pierwszy z nich to ochrona meteorologiczna lotnictwa polegająca na dostarczaniu prognoz, map synoptycznych oraz wszelkich informacji i danych meteorologicznych niezbędnych dla ruchu lotniczego. Przekazywano także dane dla pułków i szkół lotnictwa wojskowego ${ }^{66}$, jak również dla portów lotnictwa cywilnego. Do drugiej grupy zadań należało: dostarczanie danych i informacji meteorologicznych innym rodzajom broni - zwłaszcza artylerii, obronie przeciwlotniczej i przeciwgazowej oraz Marynarce Wojennej. Trzecia grupa zadań to współpraca z PIM oraz organami służby meteorologicznej Ministerstwa Komunikacji oraz Departamentem Lotnictwa Cywilnego tegoż Ministerstwa ${ }^{67}$.

W skład Kierownictwa Służby Meteorologicznej oprócz jego kierownika wchodził zastępca, sekretarz, kierownik sekcji synoptycznej i spostrzeżeń oraz dowódca kompanii szkolnej. Sekcja synoptyczna prowadziła prace odpowiadające wydziałom synoptycznym cywilnych instytutów meteorologicznych - oczywiście dostosowanych do potrzeb wojska. Sekcja spostrzeżeń prowadziła obserwacje meteorologiczne oraz aerologiczne $e^{68}$ na potrzeby armii. Kompania szkolna była odpowiedzialna za szkolenie: oficerów (także rezerwy), podoficerów zawodowych służby meteorologicznej, szeregowców dla wspomnianej służby oraz meteorologiczne personelu latającego polskich sił powietrznych ${ }^{69}$.

Kursy meteorologiczne trwały trzy miesiące. Składały się z części teoretycznej - obejmującej całokształt zagadnień wiedzy meteorologicznej oraz praktycznej - prowadzenie ochrony meteorologicznej lotnictwa. Z kolei na kursie

Kraków 2006, s. 224 i 503. Zastępcą mjr. pil. K. Zacharewicza był kpt. pil. Piotr Hiksa. Kierownictwo mieściło się na Okęciu.

${ }^{66}$ Najważniejszą z tych szkół była Szkoła Podchorążych Lotnictwa w Dęblinie (od 1929 r. nosząca nazwę Centrum Wyszkolenia Oficerów Lotnictwa) - popularnie zwana „Szkołą Orląt”. Wymienić też wypada: Szkołę Podoficerów Lotnictwa dla Małoletnich w Bydgoszczy (od 1938 r. w Krośnie). Szerzej o szkolnictwie lotniczym: S. RUTKOWski, Zarys dziejów polskiego szkolnictwa wojskowego, Warszawa 1970; A. Przedpeeski, Lotnictwo Wojska Polskiego 1918-1996. Zarys historii, Warszawa 1997.

${ }^{67}$ CAW WBH, Oddz. II SG, sygn. I.303.4.4538. Organizacja służby meteorologicznej w czasie pokoju w Polsce, s. 2.

${ }^{68}$ Aerologia to dział meteorologii zajmujący się badaniem procesów i zjawisk zachodzących w górnych warstwach atmosfery.

${ }^{69} \mathrm{CAW}$ WBH, Oddz. II SG, sygn. I.303.4.4538. Organizacja służby meteorologicznej w czasie pokoju w Polsce, s. 3 . 
aerologicznym, także trzymiesięcznym, jego uczestnicy poznawali tajniki aerologii oraz oprzyrządowanie badawcze. W części praktycznej odbywali loty pod kierownictwem doświadczonych meteorologów wojskowych. Po takich kursach oficerowie zostawali kierownikami sekcji meteorologicznych na lotniskach. Podoficerowie byli szkoleni przez cztery tygodnie, a szeregowi przez trzy i pół miesiąca ${ }^{70}$.

Pierwszy kurs meteorologiczny dla podoficerów zawodowych zorganizowano 1 marca 1926 r. Organizatorem była Główna Wojskowa Stacja Meteorologiczna w Warszawie. Na trwający trzy miesiące kurs zapisywano chętnych podoficerów od listopada 1925 r. Kandydaci powinni mieć ukończoną szkołę powszechną oraz odznaczać się wysokimi kwalifikacjami zawodowymi i moralnymi. Po przyjęciu na kurs podoficerowie byli zobowiązani do trwającej dwa lata służby w pododdziałach meteorologicznych. Przewidywano także przyjmowanie starszych szeregowców, którzy ukończyli z wynikiem pomyślnym szkołę podoficerską. Byli oni zobowiązani do trwającej sześć lat służby ${ }^{71}$. W tym samym roku, w dniu 15 czerwca otwarto kurs dla podoficerów artylerii, a to z uwagi na fakt, że - obok lotnictwa i marynarki - ten rodzaj broni potrzebował najwięcej informacji o warunkach pogodowych ${ }^{72}$.

Od początku lat trzydziestych prowadzono w WP półroczne kursy dla oficerów różnych rodzajów broni - zwłaszcza artylerii, w zakresie współdziałania z lotnictwem. W programie szkolenia na ogółem 591 godzin kursu, przewidziano 16 godzin na zapoznanie oficerów z wiedzą meteorologiczną - w tym 10 na zajęcia praktyczne, czyli udział w lotach obserwacyjnych ${ }^{73}$.

W służbie meteorologicznej armii II Rzeczypospolitej wykorzystywano dość bogatą listę przyrządów i pomocy naukowych. Przede wszystkim były to barometry rtęciowe mierzące ciśnienie atmosferyczne, barografy, czyli barometry wyposażone w urządzenie do rejestracji dokonywanych pomiarów ciśnienia atmosferycznego ${ }^{74}$, wysokościomierze, statoskopy, tzn. przyrządy pokładowe

${ }^{70}$ Ibidem, s. 3-4.

71 CAW WBH, Oddz. III SG, sygn. I.303.5.90. Pismo Departamentu IV MSWojsk. z 18 XI $1925 \mathrm{r}$.

72 Ibidem. Otwarcie I-go kursu meteorologicznego dla podoficerów zawodowych artylerii, czerwiec $1926 \mathrm{r}$.

${ }^{73}$ Ibidem. Zasady ogólne kursu wiedzy lotniczej, 2 I 1930 r. - 30 VI 1930 r.

${ }^{74}$ Barografy są elementem rejestratorów stanu pogody badających ciśnienie, temperaturę i wilgotność powietrza, jak np. barotermografy. 
samolotów wskazujące małe zmiany wysokości lotu. $\mathrm{Na}$ wyposażeniu stacji meteorologicznych znajdowały się także termometry, hydrografy rejestrujące samoczynnie poziom wody, psychrometry mierzące poziom wilgotności powietrza w pomieszczeniach ${ }^{75}$, manometry służące do pomiaru ciśnienia względem ciśnienia otoczenia ${ }^{76} \mathrm{czy}$ balony meteorologiczne ${ }^{77}$.

Służby meteorologiczne współpracowały także z wywiadem i Samodzielnymi Referatami Informacyjnymi Dowództw Okręgów Korpusów. Niepokój w okręgach budziły aparaty meteorologiczne przyczepione do spadochronów bądź baloników, wypuszczane przez obce państwa. Oddział II Sztabu Głównego wyjaśniał oficerom SRI DOK, że „aparaty te służą do pomiarów prądów powietrznych [...] Dotychczas Oddział II Szt. Gł. nie stwierdził, ażeby aparaty te, względnie baloniki były wykorzystywane do innych celów niż naukowe. Nie jest rzeczą wykluczoną, że na wypadek wojny omawiane baloniki mogą być użyte w wielkich ilościach, jako środek propagandy wywrotowej" ${ }^{\prime 8}$. Zalecano, aby z okręgów korpusów odsyłać je do służb meteorologicznych WP. O wysłaniu takich baloników informowały często państwa sąsiednie, jak np. w $1924 \mathrm{r}$. zrobiło to Poselstwo Republiki Czechosłowackiej ${ }^{79}$. Odpowiednie instrukcje II Oddział SG WP wydawał także Komendom Policji Państwowej w komisariatach nadgranicznych ${ }^{80}$.

Warto dodać, meteorologia pomagała także „sobie samej”. Ważne było, aby klisze, materiał fotograficzny czy przyrządy utrzymywać w odpowiedniej temperaturze, wilgotności, na specjalnych podestach, aby uchronić je od uszkodzenia mechanicznego lub zalania ${ }^{81}$. Już na początku lat trzydziestych postulowano,

75 http://wm.pollub.pl/pl/wydzial-mechaniczny/katedra-termodynamiki... Pomiary wilgotności powietrza 2013 [dostęp: 31 X 2019].

76 Encyklopedia fizyki, t. 2, Warszawa 1973, s. 270; W. TRYLIŃski, Drobne mechanizmy i przyrządy precyzyjne. Podstawy konstrukcji, Warszawa 1978, s. 193-194.

77 CAW WBH, Oddz. IV SG, sygn. I.303.7.457. Zestaw przyrządów meteorologicznych i materiałów pomocniczych Sekcji Spostrzeżeń Głównej Wojskowej Stacji Meteorologicznej. Lista obejmuje ponad 500 pozycji.

78 CAW WBH, Samodzielny Referat Informacyjny [dalej: SRI], Dowództwo Okręgu Korpusu [dalej: OK] IX, sygn. I.371.9/A.7. Pismo Oddziału II SG z 13 VI 1938 r. Dowództwo OK IX stacjonowało w Brześciu nad Bugiem.

79 CAW WBH, Odd. II SG, sygn. I.303.4.141. Pismo z 30 V 1924 r.

80 Ibidem, Pismo do SRI OK nr V w Krakowie z 28 IV 1925 r.

81 CAW WBH, Biuro kontroli, sygn. I.300.17.105. Przechowywanie i konserwacja materjałów wojskowych. Materjał foto; Instrukcja o przechowywaniu i konserwacji materjału meteorologicznego, Warszawa, sierpień 1935 r. Materiałem wybuchowym podatnym na oddziaływanie wysokich 
aby ze służbą meteorologiczną współpracowali chemicy ze służby uzbrojenia, jako że materiały wybuchowe zachowują się różnie w zależności od temperatury czy wilgotności powietrza w pomieszczeniach magazynowych ${ }^{82}$.

O wysokim poziomie polskich służb meteorologicznych armii II Rzeczypospolitej świadczy m.in. fakt, iż o informację o jej organizacji poprosił na początku marca 1938 r. attaché wojskowy Finlandii H. von Essen. Z uwagi na kwestie tajemnicy wojskowej zgodę musiał wyrazić ówczesny szef Oddziału II Sztabu Głównego. Pułkownik Tadeusz Pełczyński - szef polskiego kontrwywiadu i wywiadu - wydał w tej sprawie zgodę w połowie kwietnia roku $1938^{83}$.

Działalność polskiej służby meteorologicznej i hydrograficznej, choć była to służba ważna dla sprawnego funkcjonowania armii II Rzeczypospolitej, rzadko jest przedstawiana w opracowaniach poświęconych dziejom WP. Autorzy wspominają raczej tylko o warunkach pogodowych, ale nie piszą o pracy służb prognozujących warunki atmosferyczne ${ }^{84}$. Była to także stosunkowo nieduża kadrowo służba WP, ponadto ściślej - niż inne służby wojskowe - związana z cywilnymi instytucjami meteorologicznymi i hydrograficznymi państwa polskiego. Było to specyfiką tej służby armii II Rzeczypospolitej. Niemniej warto jej było poświęcić nieco uwagi, choćby dlatego, że działalność meteorologów w wojskowych mundurach stała dotąd w cieniu pozostałych rodzajów broni oraz innych służb WP w latach 1918-1939. Trzeba też z całą mocą podkreślić, iż była to służba bardzo nowocześnie zorganizowana, wyposażona także w nowoczesny sprzęt badawczy oraz współpracująca z licznymi placówkami naukowymi, w tym z Wyższą Szkołą Wojenną w Warszawie.

Niniejszy artykuł stanowi pierwszą próbę spojrzenia na działalność służby meteorologicznej i hydrograficznej WP. Autor przejrzał dość skromną literaturę przedmiotu oraz 20 zespołów akt (34 teczki) zgromadzone w CAW, wchodzącym w skład Wojskowego Biura Historycznego. Dodajmy, że przed 1939 r. były to

temperatur jest dynamit. Lepiej „znosi” wysoką temperaturę otoczenia trotyl. Szerzej o problemach technicznych: M. Korzun, 1000 stów o materiatach wybuchowych i wybuchu, Warszawa 1986, s. 73; S. CudziŁo, Wojskowe materiaty wybuchowe, Częstochowa 2000, s. 386.

82 CAW WBH, Oddz. I SG, sygn. I.303.3.26. Raport z 29 IX 1932 r., k. 278.

83 CAW WBH, Oddz. II SG, sygn. I.303.4.4538. Pismo Oddziału II SG nr 24398/II Og. z 13 IV 1938 r.

${ }^{84}$ Kampania Wrześniowa 1939. Bibliografia, t. 1-2, oprac. I. KowALSKa, I. SAWICKA, Warszawa 2002, passim. 
właściwie dwie służby, wprawdzie współpracujące ze sobą, ale odrębne organizacyjnie. W chwili obecnej, od 1 stycznia 2011 r. funkcjonuje Szefostwo Służby Hydrometeorologicznej Sił Zbrojnych Rzeczypospolitej Polskiej w Warszawie ${ }^{85}$.

\section{BIBLIOGRAFIA}

\section{Źródła archiwalne}

\section{Centralne Archiwum Wojskowe w Warszawie}

Biuro Kontroli, sygn. I.300.17.105.

Departament Spraw Morskich i Kierownictwo Marynarki Wojennej, sygn.: I.300.21.82, I.300.21.412.

MSWojsk. Departament Budownictwa, sygn. I.300.63.5.

MSWojsk. Dowództwo Lotnictwa, sygn. I.300.38.112.

MSWojsk. Inspektorat Wojsk Lotniczych, sygn.: I.300.39.11, I.300.39.16.

MSWojsk. Instytucje Kontroli, sygn. I.300.17.105.

Oddział I NDWP, sygn. I.301.7.14.

Oddział IV NDWP, sygn. I.301.10.164.

Szefostwo Lotnictwa NDWP, sygn.: I.301.12.3, I.301.12.43, I.301.18.19.

Oddział I SG, sygn.: I.303.3.26, I.303.3.97, I. 303.3.204, I.303.3.230, I.303.3.277, I.303.3.320.

Oddział II SG, sygn.: I.303.4.141, I.303.4.4538.

Oddział III SG, sygn. I.303.5.90.

Oddział IV SG, sygn.: I.303.7.32, I.303.7.457.

Sztab Lotniczy, sygn. I.303.10.27.

Oddziały Marynarki Wojennej, sygn. I.328.1.4.

SRI DOK IX, sygn.: I.371.8.195, I.371.9/A.7.

Sztab Lotniczy SG, sygn. I.303.10.27.

Szkoła Podchorążych Lotnictwa (grupa techniczna), sygn.: I.340.52.7, I.340.52.8.

Wojskowe Zakłady Przetwarzania, sygn. I.362.1.153.

Wyższa Szkoła Wojenna, sygn. I.340.1.152.

85 https://pl.wikipedia.org/wiki/Szefostwo_Służby_Hydrometeorologicznej_Sit_Zbrojnych... [dostęp: 20 XI 2019]. 


\section{Źródła drukowane}

Rocznik Oficerski 1939. Stan na dzień 23 marca 1939, Kraków 2006.

„Dziennik Praw Państwa Polskiego” 1919.

„Dziennik Ustaw” 1922.

\section{Wspomnienia}

Kłossowski J., Wspomnienia z Marynarki Wojennej, Warszawa 1977.

\section{Opracowania}

80 lat państwowej stużby hydrologicznej i meteorologicznej w Polsce, Warszawa 1999.

Ambrose S.E., D-Day 6 czerwca 1944, Warszawa 1999.

Borowiak M., Admirat. Biografia Józefa Unruga, Gdańsk 2004.

Ciesielski C., Pater W., Przybylski J., Polska Marynarka Wojenna 1918-1980. Zarys dziejów, Warszawa 1992.

Cudziło S., Wojskowe materiaty wybuchowe, Częstochowa 2000.

Cummins J., Francis Drake, Warszawa 2000.

Dziewanowski K., Brzemię biatego cztowieka, t. 1, Warszawa 1981.

Encyklopedia fizyki, t. 2, Warszawa 1973.

Ericson C., Elżbieta I, Warszawa 2001.

Flis J., Szkolny stownik geograficzny, Warszawa 1985.

Grodziski S., Polska w czasach przetomu. 1764-1815, Kraków 2001.

Kadry morskie Rzeczypospolitej Polskiej, t. 5: Polska Marynarka Wojenna. Dokumentacja organizacyjna i kadrowa oficerów, podoficerów i marynarzy (1918-1947), red. J.K. Sawicki, Gdynia 2011.

Kampania Wrześniowa 1939. Bibliografia, t. 1-2, oprac. I. Kowalska, I. Sawicka, Warszawa 2002.

Kopacz Z., Morgaś W., Kierzkowski W., Nitner H., Powstanie Urzędu Hydrograficznego Marynarki Wojennej, „Nautologia” 1999, t. 34, nr 2, s. 29-40.

Korzun M., 1000 stów o materiatach wybuchowych i wybuchu, Warszawa 1986.

Kukiel M., Wojna 1812, Poznań 1996.

Łysejko A., 70-lecie hydrografii w Polsce, „Przegląd Morski” 1990, t. 43, nr 2, s. 13-18.

Markert W., Arnhem 1944, Warszawa 2006.

Miciński J., Księga statków polskich 1918-1945, t. 1, Gdańsk 1996. 
Midowicz W., O Biatym Stoniu na Czarnohorze, „Harnaś. Materiały szkoleniowe Studenckiego Koła Przewodników Górskich Harnasie" [Gliwice] 1979, s. 3-13.

Nawrot D., Historia korpusu oficerskiego Marynarki Wojennej II Rzeczypospolitej. Post scriptum, „Zeszyty Naukowe Akademii Marynarki Wojennej” 2011, t. 52, nr 1, s. 167-192.

Nitner H., Początki wspótpracy międzynarodowej w dziedzinie hydrografii morskiej, „Przegląd Morski” 1995, t. 48, nr 9, s. 29-31.

Osowicka R., Piaśnica. Miejsce martyrologii i pamięci, Wejherowo 2001.

Pawlak J., Polskie eskadry w latach 1918-1939, Warszawa 1989.

Piwowoński J., Flota spod biato-czerwonej, Warszawa 1989.

Przedpełski A., Lotnictwo Wojska Polskiego 1918-1996. Zarys historii, Warszawa 1997.

Rapiński P., Lotnictwo Armii „Łódż”, Łódź 2018.

Różdżyński K., Stachurska E., Polska stużba meteorologiczna i hydrologiczna na Morzu Battyckim w latach 1920-1988, [w:] 70-lecie Państwowej Służby Hydrologiczno-Meteorologicznej. Referaty problemowe, Warszawa 1989, s. 122-144.

Rutkowski S., Zarys dziejów polskiego szkolnictwa wojskowego, Warszawa 1970.

Stachula A., Obrona powietrzna Polski 1918-1939, cz. 1, Jelenia Góra 2009.

Tryliński W., Drobne mechanizmy i przyrządy precyzyjne. Podstawy konstrukcji, Warszawa 1978.

Wielka historia świata, t. 9: Świat w latach 1800-1850, red. A. Chwalba, Kraków 2006.

Zieliński J., Polska państwowa stużba hydrologiczno-meteorologiczna $w$ 70-lecie swego istnienia, [w:] 70-lecie państwowej stużby hydrologiczno-meteorologicznej. Referaty problemowe, Warszawa 1989, s. 15-37.

\section{Netografia}

https://docplayer.pl/37259188-kalendarium-sluzby-hydrograficznej [dostęp: 21 X 2019].

https://pl.wikipedia.org/wiki/Biuro-Hydrograficzne_Marynarki_Wojennej [dostęp: $12 \mathrm{X}$ 2019].

https://pl.wikipedia.org/wiki/Obserwatorium_Astronomiczno_Meteorologiczne_na_ szczycie_Pop_Iwan [dostęp: 31 X 2019].

https://wm.pollub.pl/pl/wydzial-mechaniczny/katedra-termodynamiki... Pomiary wilgotności powietrza 2013 [dostęp: 31 X 2019].

https://pl.wikipedia.org/wiki/Szefostwo_Służby_Hydrometeorologicznej_Sił_Zbrojnych... [dostęp: 20 XI 2019]. 


\section{Konrad A. Czernielewski}

\section{METEOROLOGICAL SERVICE OF THE POLISH ARMY 1919-1939}

Summary. The author of the article discussed the history of the meteorological and hydrographic service of the Polish Army in 1919-1939. At the beginning of his considerations, he presented a brief outline of the development of meteorological and hydrographic observations in Poland from the end of the Middle Ages to the outbreak of World War I. He showed the beginnings of forming state and military meteorological and hydrographics service in 1919. He devoted a lot of attention to the activities of the State Institute of Meteorology - an institution closely cooperating with the Ministry of Military Affairs, the General Staff of the Polish Army and its branches.

He also presented the history of the hydrographic services of the Polish Navy. Before 1939, Poland had great achievements in hydrographic research. As early as 1926, she became a member of the International Hydrographic Office based in Monaco. The Navy's Hydrographic Office was the official representative of Poland in the International Bureau.

The author devoted a lot attention to the activities of meteorological services for the Polish aviation - mainly military, but also the cooperation of military meteorologists with Polish artillery and armaments service. He acquainted readers with the issues of training meteorological and hydrographic services in Poland in 1918-1939. He also presented the organizational structure of these services and their commanding staff. He introduced readers to technical issues: he presented the instrumentations, ways and methods for observing natural phenomena and recording them.

In final conclusions he presented his assessment of the activities of meteorological and hydrographic services of the Polish Army. He rated them very highly - they were well organized and well equipped with specialist equipment, they cooperated with numerous scientific institutions. They were highly rated in the interwar period by representatives of European armies. This is evidenced by the fact that at the beginning of March 1938 he asked for information about the organization of Polish meteorological and hydrographic services to the Military Attaché of Finland.

Keywords: meteorology, hydrography, military meteorological service, military hydrographic service, military intelligence, military counterintelligence, Navy, Military aviation, Ministry of Military Affairs, State Institute of Meteorology 